\title{
Study on Integration and Promotion of Humanistic Quality and Tourism Professional English Ability Improvement
}

\author{
Lin $\mathrm{Li}^{1, \mathrm{a}}$ \\ ${ }^{1}$ Department of Public Foreign Language Teaching \& Research, Guilin Institute of Tourism, Guilin, \\ 541006, China \\ aemail: lilin9923@126.com
}

Keywords: Humanism Education; Higher Vocational; Tourism; Professional English Ability

\begin{abstract}
A At present China's higher vocational tourism talents cultivation encountered bottleneck: On the one hand, China's foreign-related tourism industry urgently needs to have stronger strong professional English proficiency of high-quality compound talents. On the other hand Vocational Tourism Vocational English Teaching is still exam-oriented education in China, Design of the materials is not reasonable, the enthusiasm of the students is not high, and these problems are not conducive to students of tourism vocational English proficiency. This paper points out that: to solve this problem, should from the humanism education perspective, uses the humanism teaching method and teaching means, Such as community language learning method, students' humanities quality and the integration of tourism professional English ability, so as to cultivate and promote the tourism professional English ability of students, Through such teaching activities and teaching feedback, and we find that humanistic quality education in the vocational English teaching, the tourism professional English ability of students is improved. Proved: for a long time, cultivate human qualities of the vocational high school students have been taken seriously,, And is rare in tourism vocational English education will cultivate students' humanities quality and tourism professional English ability of specific ideas and implementation plan, In this paper, in this aspect are discussed.
\end{abstract}

\section{Present Stage of Vocational Colleges Tourism English Teaching}

After China's entering to the WTO, the tourism industry has encountered unprecedented opportunities and challenges, China's tourism vocational English teaching is also facing innovation and reform. the purpose of tourism professional English teaching is to cultivate interdisciplinary talents with good tourism professional English ability. Higher vocational tourism English professional ability of students is a measure of one's professional ability. But China's current vocational tourism vocational English education is serious: First of all, from the overall English learning point of view of the learning subject, the university entrance English scores generally low, they master the basic knowledge of English is not solid, Even some of the most didn't grasp the basic language knowledge, English knowledge reserves in tourism professional English is difficult to support and continue to learn, From the students' English learning status, learning enthusiasm is not high, the interest of learning English is not enough, they are not good at spontaneously using learning methods and learning strategies to promote their own learning[1]; Second, according to the existing teaching mode, theoretical class hours and the arrangement of the practice is not reasonable, namely, college English and professional English course schedules appeared the phenomenon of one-sided, Either the hours of college English accounted for the vast majority of credit hours, or simply even the most basic college English class hours to get rid of, either too long or too short to arrange internships for students, For students, learning English is to cope with the English exam, many students in the research are lost and disoriented.

On the one hand, school facilities is not perfect, on the one hand the university-enterprise cooperation channel is not unobstructed, In the process of social and school docking, some student's qualities influence their performance in the internship; From the aspect of teaching material, based on an article, each unit is designed to cover blank-filling, reading comprehension, cloze, 
single-sentence translation, and it particularly raise student's beginning ability, ability of thinking in English oral expression ability. Such structure seems to weigh theories more and ignore training students' professional English ability [2]. As to the teachers' role, the performance of tourism professional English teachers is not satisfactory: Many teachers' major is English language and literature, they have a solid English language foundation of basic skills, but they don't have a line in the tourism industry, they lack corresponding tourism theory and practical working experience. Its leading role in specific ESP teaching is limited by professional disciplines and can't take good effects. That suggests finding scientific and effective method as soon as possible in training tourism professional English ability of students in higher vocational colleges [3].

\section{Humanistic Psychology and Humanistic Education}

Humanistic education is an important school of the education thought of the contemporary west, its representative figure is Rogers, and Rogers is one of most influential humanistic psychologist today. Rogers' education comes directly from his "person-centered" psychological counseling theory and practice, which is totally different from traditional ones; he believed the decisive factor of curing patients is their abilities instead of doctors' knowledge and experience. So the core of Rogers humanism education is the interpretation of whole-man. First of all, he sees everyone as the center of certain experience in the world; the center is in a state of permanent change. On being formed, self will become the decisive factor of affecting the individual behavior, Therefore, to understand a person's behavior; we should play the role of him to observe the world. Third, everyone has an instinct to protect themselves, to improve themselves and to realize self, this is the most basic motive and purpose. Fourth, one's greatest achievement is to play his role thoroughly in his life, being able to accept others and being harmony with others. In Rogers' view, emotion and cognition-two elements in the human spiritual world are inextricable. The fundamental goal of education is to cultivate a whole-person who can propose at the good command of his IQ and EQ.

In short, humanism teaching view believes that the growth and development is that people are born with natural instincts. Curran use the relationship of the incarnation and redemption to his and his team developed CLL community language learning method, namely in the learning process, learners from totally dependent on the teacher to completely independent learning process, is the so-called perfect process: This gives us an important enlightenment, teacher in the teaching process should pay attention to help students self-improvement, self-improvement, by helping them to self value so as to promote their learning [4].

\section{To Develop Higher Vocational Tourism Professional English Ability by Carrying Out Humanism Teaching Activities}

Rogers' humanism education provides us enlightening approaches to cultivate higher vocational tourism college students. That is to create a secure and friendly environment to develop their abilities by realizing their maturity.

Humanistic Quality and Tourism Vocational English Proficiency. Humanistic quality should be considered as the elementary part of tourism professional ability. With the help of the teacher, the gradual integration of humanistic quality is supposed to penetrate to the inner quality that an individual need [5]. In real life, personal humanistic quality consists of the following factors: knowledge, ability, conception, emotion and will. Humanistic quality is very abstract and comprehensive content, but a person's cultural quality can be explicitly illustrated through a person's speech, demeanor, temperament, looks, manners, etc [6]. Humanistic quality is the foundation of modern comprehensive quality; a person can accept normal good education to cultivate their humanistic quality, to start his future career. It mainly includes two parts: one is the humanistic knowledge; the second is the humanistic spirit. Humanities knowledge is about the basic knowledge of the humanities, such as history, literature, law, knowledge, art, aesthetics, philosophy, religion, culture, moral awareness, language use, etc. Humane mainly relates to ideological and moral quality, values, outlook on life, world outlook and personality quality and culture, etc. Humanistic spirit thinks high of value of man, defend human dignity, stimulate their potential, and cultivate their mind. 
Determined people in the workplace can cope with varieties of difficulty; Engaged in tourism especially foreign-related tourism, temperament and manner, ability to communication with people is essential, which are based on can be obtained through cultivating students' humanistic quality. Under the new situation, the process of global integration will encounter the problem of culture shock, culture collision, if one has weak awareness of his own nationality; he is prone to suffer from identity confusion. So the cultivation of humanistic quality is the foundation of the tourism professional English ability training for higher vocational students.

The Selection of Teaching Materials and Teacher-Team Construction. Textbooks are essential in class teaching, so first we should write and edit bilingual teaching materials fitting for higher vocational students. Bilingual teaching is not only the main basis of teaching, but also the most direct, the most comprehensive elements to foster $t$ he talents. It is the media and the foundation of cultivating tourism professional talents, directly relevant to the teaching effect. And many of the school personnel training mode has adopted new methods such as enterprise-college cooperation and provide students relevant psychology guidance. Students are encouraged to write work diary during the internship to help students to reflect on your growth course, which can also provide teachers first-hand information for teaching material writing. Second, building a strong, professional language proficient teacher team is very important; the teaching material can make a big difference with teachers' are being involved. Culture import, technical guidance and psychological counseling promise students' humanities quality blending with the ability of the tourism professional English.

\section{Humanistic Activities and English Training of Professional Competence.}

Humanism Quality Penetration in English Vocational Education. Humanistic quality is the foundation of the tourism professional English ability, higher vocational colleges should carry out a variety of colorful extra curriculum activities. According to Rogers' 'person-centered' principle, the person's mental and emotional developments are as important as his physical health. Humanism learning activities to let students give full play to their potential. In learning knowledge at the same time, also learn how to establish a good interpersonal relationship with others. As the author of Guilin institute of tourism schools of humanism extracurricular activities such as college students career planning, guiding talent competition, organizes the student to attend Guangxi foreign language festival activities, the English songs competition, hotel professional skill service competition, will enable students to learn knowledge and the emotion, experience and the accumulation of life experiences closely together. Through these activities, students has increased self-esteem, to realize their value and at the same time can see the strengths of others, thus a more positive approach to work, study and life. Through the penetration of humanistic quality, students learn about you, also come up, and laid a solid foundation for self-fulfillment.

Using Humanistic Language Teaching Method to Cultivate the Tourism English Professional Ability of Students. Increasing teaching methods and enriching teaching content is a vital factor in improving such as can use community language learning method to reduce language anxiety of students, cultivate the ability of the student use English thinking, control the English text and speech ability [7];Can take advantage of the natural law to cultivate the students' English communication skills; It is worth noting that is not to say that must take a certain specific teaching methods, but said that under the new situation, the teacher in the arrangement of teaching link, from concept, humanistic education can be to incorporate some elements of these methods to the concrete teaching activities, Adoption of teaching methods is based on one purpose, that is students' personal development is the primary, if one cannot fully balanced development, tourism professional English ability are all empty talk.

Teach the Student how to Reflect. The role of reflection as to help students find their own emotions, more important is through reflection, help students in cognition but also promote. Reflection process is very simple actually, memories and remember things as much as possible, the details of the analysis of reasons, especially analysis the cause of the failure, the teachers should help students to get rid of the congenital remorse mechanism, is the students tend to pay more attention to the result of a failure of feeling while ignoring the cause of failure, To imagine things the process, to change an Angle thinking problem, what the decision according to the results of the analysis is to take measures. Under the care of humanism education, combining with the status quo of China's current tourism English professional education, to explore how to cultivate higher vocational students of 
tourism English professional ability is a very realistic topic, there are many needs to be further exploration of space.

\section{Conclusions}

According to the current situation in China, teaching activities are a bit relevant to the need of the personnel market. The core of the problem is that humanism education principle -cultivating 'whole-person' has long been ignored. From this aspect, we should take innovation approaches to improve our teaching activities by rewriting the textbooks, designing curriculum, constructing teacher teams, improving teaching equipments and facilities. By employing humanistic techniques to promote students’ qualities, we will make a great progress.

\section{Acknowledgment}

This paper is supported by the "Guangxi Provincial Guilin Institute of Tourism scientific research fund for youth project [2011] No. 2011QN13”, I express my gratitude to it.

\section{Preference}

[1] Ch.Yu. Hong Kong Vocational Education Experience and the Ability of the University Students[J], Chinese Journal 2011 vol.4, pp.115,154.

[2] Y.F. Qian, Y.S.Li, Zh.Q.Feng, The Vocational Ability Training Study English in Tourism Management Professional Students[J], Journal of vocational and Technical college in Shanxi Province, 2010, vol.6, pp1-6.

[3] Y.Li, Tourism Professional in Higher Vocational Bilingual Teaching ReformsEducation and Vocational, 2011(5), pp.12-126.

[4] Y.Q.Feng, The Shallow of Culture Teaching in College English Teaching[J], Journal of Nanchang Institute of Education, 2010,25(4), pp.132-133.

[5] J.Lu, On the Penetration and Fusion of Human Education in English Teaching[J], Jingling Institute of Technology (Social Science Edition)19, No.1, March 2005, pp.105-108.

[6] Hu Min, College English Teaching and Humanistic Quality Education[J], Journal of Jiangxi blue sky college(supplement), 2008(10),pp.60-62.

[7] R.J.Zhang, The Humanism teaching method, the ESP teaching and humanistic Quality of English Teaching[J], Journal of Shandong Foreign Language teaching, 2000 vol.4. 